\title{
How Nature Disaster Influences International Relations: An Comparative Analysis Between Great Influenza and Covid-19 Pandemic
}

\author{
Xianping Liu ${ }^{1, *}$ \\ ${ }^{1}$ MGIMO University, Moscow, 119454, Russia \\ *Corresponding author. Email: yliu@nufe.edu.cn

\begin{abstract}
This paper uses a comparative study to examine the surprising similarity of two disasters in 1919 and 2019 with the lens of international relations. This article starts with the background of the two pandemics, both of which are located in Thucydides' trap. Then the paper uses governments' hiding policies and diplomatic battle to picture the common point of both pandemics. Plus, this article examines the effects of both pandemics, which enlarge counties' gaps and speed the growth of extremists.
\end{abstract}

Keywords: similarity, common, international relations, Influenza, Pandemic, Spanish Flu, Covid, Covid-19.

\section{INTRODUCTION}

About the two most deadly pandemics in modern history: Great Influenza was called the Spanish Flu one century ago. Its massive outbreak happened at the end of WWI in 1919 in the European continent. This pandemic lasted three waves and killed nearly fifty million population. As for Covid-19, it was first reported in China. Then it fast spread to many countries. Until today no one had a clear vision about the end day of Covid-19.

Pandemics aggravate the existing international situation and bring tensions to a boil. The global situation is on the worst level of international relations for the last two decades. Nature disasters, like these two pandemics, play a significant role in world structure. However, there was not much paper discussing the similarity of two pandemics in international relations. This paper aims to illustrate their commons and similarities through the comparative study. The paper is trying to question the world if two disasters step on the familiar path and lead in the same direction. The question is essential because Great Influenza indirectly led the world rush to WWII. The purpose of writing this paper is to compare and summarize the path of Great Influenza and Covid-19 and help illuminate the future of the post-pandemic world.

Some of these incidents are pretty unreasonable for the public to say, such as the delayed transmission of information, the government's initial passive response to the epidemic, and racial discrimination. This paper separated these two events into several affairs to distinguish the similarity. Both pandemics have the same issues. This striking similarity led to the question of whether we were once heading in the same direction.

The background section generally paints the complete picture of Great Influenza and Covid-19. Section 3 discusses that they both happened in international relations' chaos and the relation among main power was intensive. Section 4 describes the delay phenomenon, which indicates rounds of delays in responding and information sharing during both pandemics. Then Section 5 thoroughly reviews about the diplomatic battle about nickname effect in the international relation. The last section illustrates the damages that a massive pandemic can generate. At the end of the paper, the two pandemics are summarized, and the future development of international relations is forecasted.

\section{BACKGROUND}

Covid-19 and Great Influenza are the most deadly pandemic in modern history. They killed huge populations worldwide and targeted different age groups with a different type of virus. Great Influenza was first written in the official document on American's campus in Kansas during WWI. Soon the virus diffused over the world along with the soldiers' transmission between continent and colonies. Plus, the poor sanitation and war 
hurt the soldiers' mental health. Then the massive outbreak began in Europe at the later phase of the war. Moreover, the international state after WWI caused many delays and errors that should not have occurred. Information was manipulated for various reasons. Great Influenza lasted three waves of outbreaks and killed 21.5 million people based on early reports [1].

During the second wave, the mortality rate reached a peak. As a result, the death number was higher than the war, which caused the significant reduction of the labor force and stimulated racism and fascism.

Covid-19 was first announced on social media by a Chinese doctor at the beginning of 2020 before the Chinese spring festival. At the same time, the world was enjoying the benefit of globalization. The enormous scale of population mobility, multiple trade flows, and continuing development of technology give the virus opportunities to travel worldwide. The advanced air transport easily passes the virus to every country. The first outbreak happened in China. It is a different kind of virus, but it upgraded faster and more innovative than Great Influenza. Therefore many countries believed that either China or USA created it. Is it the "Wuhan virus" or "Fort Detrick virus"? Led many rounds of diplomatic battles and enlarged the international relations conflicts. Until 22 September, it killed 4,56million lives and kept variate into more robust versions. Modern society has a more significant population, and goods flow makes it difficult to stop compared with the Great Influenza.

In both pandemics, the virus tipped the scales favoring the rich - the proportions of poor people dead most. For example, during the Spanish Flu in colonized India, the mortality reached 18 million [2]. India took the first place of death mortality worldwide. While today, after 100 years, countries with no ability to process vaccines are as fragile as the old India.

\section{COMPARISONS OF TWO PANDEMICS}

Through the comparison of two pandemics, four similarities can be found below. They both happened at the time when the world was located in the Thucydides' trap. All the governments denied and delayed the critical information about the two pandemics. These two pandemics were both named after the nation for a while. They both indirectly threaten the stability of international relations.

\subsection{International relations, conflicts, and Great Influenza.}

Before WWI and Great Influenza, international relations were unstable, and conflicts between old Great powers and Germany rose on many fields. There was an economic interest dispute between the old Great powers and Germany. Germany desired Polish territory that
Russian empires traditionally controlled. There were also political disputes between them. Germany's enlarged political influence made the old power feel threatened. So the UK tried to block it in case its power spread to the Balkan Peninsula. As the result of Germany's ambition, great powers hold extreme hostility to this young challenger. Many scholars tend to describe such a phenomenon as the Thucydides trap. Moreover, war is always the destiny of the trap. Eventually, the war started.

Great Influenza happened during WWI- one of the most important events in modern history. It is the first time, within a war, almost all countries were involved. The battles happened most in the European continent, other in Great powers' colonies. To win the war, the Allies took the colonists to Europe to solve the problem of insufficient soldiers. This enormous population transmission allowed many kinds of bacterial and viruses to meet up in Europe. In 1916-1918, there was Lumia passed inside the colonist soldiers. For now, to say, it was like a sign of the coming Great Influenza. The war and military actions created a perfect condition for its outbreak. There were jam campuses, multi-nation battlefield, poor diet, mental stress, no sanitation knowledge, no pandemic reporting system, and no vaccinations before mixing military. The first case was reported in the April of 1918 on US soldiers Haskell, Kansas [3].

Moreover, during WW1, the flow of soldiers crossed the Atlantic between the European and American continents. Soon the virus took the chance to travel to all armies. In Europe, soldiers were infected on the campus, and deaths happened mostly in healthy males about 20 40 years old. Step by step, it appeared in ordinary people in Spain. While Spanish people suspected the illness was brought back from France. So Spanish media first reported the Great Influenza and called it the" French Flu". However, when the public was aware of the massive outbreak. Great powers named it as Spanish Flu. Eventually, the epic population mobility allows the H1N1 virus to be elevated into the global pandemic. Moreover, war status made all society respond to the pandemic one step late. As a result, this pandemic killed more people than the war.

Based on the early report in the 1920s, it was estimated that Great Influenza killed nearly 21,5 million people. However, due to the world structure, colonies' mortality was not accurate, for example, like the inaccurate mortality counting in India [4] and China. The British Empire ruled India as a colony, and China was in a de facto partition and battling the plague. The current study suggested that more than 50 million people were killed during it. Out of this number, about one-third were Indians. 


\subsection{Before Covid-19: The tensive state of international relations.}

Before the pandemic, the world was in disorder and chaos. The global economy and political structure already faced many challenges: de-globalization, protectionism, rising nationalism, geopolitical crisis, ideologic dispute, realism policy, and organized terrorists. In the lens of traditional Anglo-Saxon countries, the world was again located in the Thucydides trap. As for the rest countries, it is the old power that tried to stop their development, and the world is rebalancing. The most outstanding conflict was shown as the trade war between China and USA, more precisely, between China and American allies. Countries issued import and export restrictions against others, especially on hi-tech products.

Many countries that once had the potential to become developed have fallen into various difficulties, typically the BRIC, now all face many troubles. The only developed one, Russia, is under the sections of the USA due to the Crimea and Donetsk problem. Nevertheless, meantime it has to keep its power in Syria, handle the challenges to its dominant place in mid-ASIA, deal with the expansion of NATO. For China, to gain ocean border made it has to face an epic scale of diplomatic problems. Plus, the trade disputes with Australia, domestic protests in HK City all added pressure to China. Brazil was trapped by its weak currency system, eco problem, social inequality, and the problem around foreign policy benchmark [5]. Well, India has had the most intensive boundary line with China in the last four decades. The rising new power neither crashed with numerous issues nor struggled with the old great powers.

For the European countries, the world is not hopeful as decades ago. Terrorism, populism, the extreme party, economic problems kept intruding on them. The Southern EU was struggling with debt and illegal immigration. The Central part faces the challenge of terrorism targeting the citizens and the populists aiming the collection. All the discussions about sharing debt questioned the leadership of the EU in international relations. Also, Europe stocked in the middle of 'gas payment' and 'NATO expanding plan.' Because the expanding NATO stimulated Russia's ambition, Ukraine and the EU stand on the front line of ideological conflict.

Amid rising tensions, every international problem and humanity crisis became tools to question the legitimacy of the opponents' policies and to act more propaganda. Syrian refugees become the instrument to test whether a country is 'good' enough instead of providing enough humanitarian aid. ISIS and the Taliban threatened global safety, but countries and parties held realism as the holy bible and took the appeasement policy.

Whenever problems about justice were weaponized, that pushed international relations even closer to realism.
Feminism unexpectedly became the safety fuse on international relations for the first time. Therefore, when sexual fairness 'me too' movement was introduced to China, digital authoritarianism shut the door once for all. On the level of humankind, realism took place to dominate the world's mind. Every country was defending only its interests and nothing else. Overall, the beforepandemic international relation was in a difficult situation.

\section{DELAY INFORMATION}

The first casualty in a war is always the truth-Rudyard Kipling [6]. During the two pandemics, there were much crucial information was hidden for many reasons. The WWI's participants hid the information because of the war required. A hundred years after, again, all governments did the same thing to information about Covid-19.

\subsection{Great Influenza-delay for the war.}

The historical background of the Great Influenza was essential to explain the delay. The war was such important, so governments did not allow any negative information to disturb their army. Morale was the most concerning issue for them during the war. Therefore, the information transmission was restricted except in Spain, which was a neutral country. In 1917, the USA issued a law [7] to forbid any profane language used in the United States. No matter the word was accurate or lie.

Moreover, the press was helping the government to manipulate public will. The governments deliberately hid from their citizens and foreign governments about the infection and virus. Propaganda processed the Great Influenza to typical cold. In India's newspaper once published an article titled "nothing happened and go to bed." That explained that when governments decided to use a hiding policy to deal with the infection. Also explained why the Spanish press published so many articles to explore the truth of the pandemic. Furthermore, the Great powers decided to use propaganda to destroy its reputation to punish disturbing morale.

When the war almost ended, many countries still had substantial control over information. The vital issue for them was domestic stability. In contrast, unknown illness has no help with stability. For personnel at that time, the only resources to get information were newspapers and local governments. So in the early days of the virus's spread, many governments did not inform the public about the virus' severity. When the outbreak happened, the entire country could not find help. According to the book, the victims collapsed in the streets, hemorrhaging from lungs and nose. Their skin turns dark blue.[8] The best precautionary measures in 1919 were isolation and cleaning with soap. Nurse and volunteers tried to save patients but got infected and died. Such a story was 
repeated in the nurse's journal every day. From the hiding policy to sickness solutions and the continuing outbreaks, governments lost their reputation.

Moreover, the credibility between individual and country was gone. Because the governments was supposed to anticipate and overcome the disaster. Soon governments issued the isolation policy, but it increased unemployment. In Switzerland, workers started the protest, which ended with a military crackdown. The physical contact made the infection number reached its peak.

Indeed, the lack of medical practice, vaccines, knowledgeable doctors destroyed the world population. Nevertheless, no doubt, the delayed information should be the worst sinner of Great Influenza.

\subsection{Covid-19-delay for many rounds.}

Due to previous section' tension, the delay happened several times on information sharing, responding, and vaccination.

The first delay happens at the level of local bureaucracy in Wuhan. One Chinese doctor first reported the case of covid-19 to the domestic healthcare system at the beginning of 2020. However, the local bureau framed the doctor and hid this information for personnel interests due to the upcoming Chinese spring festivals and the National Congress, which are highly related to their own KPI. In fact, according to the government's reports, the national flu monitoring system was perfected as early as 2017[9]. The bureaucrats' mistake caused the entire province to be isolated in one night. Soon the first outbreak happened in China.

The second delay happened worldwide. It started with denying the existence of the virus, then using the mistake-held-up policy to deny the virus in the territory. Moreover, the public was misguided that self-protection has no help. In France [10], the officials publicly claimed that masks would not stop the virus, and nobody should wear them. Such voices were familiar in most countries. These lies increased the number of patients and caused a vast economic burden and social crisis, making every country had people yelling for help on social media. There is no place in hospitals, no ambulance, no pills, no medical aid, even doctors and nurses get infected.

The third-round delay happened on the vaccination process due to the trust issue. In the late article published in The Wall Street Journal by Henry Kissinger [11], nations survive and prosper based on the belief that their institutions (institutions) can anticipate impending disaster, overcome it, and restore stability. That is why the first two "delays" left a substantial trust issue between the public and government. People decided to hold their step when governments encouraged people to get vaccinated. That caused the global vaccination process to be delayed.

\section{MISTAKE: WHY NAMED THE VIRUS AFTER NATIONS?}

Despite the 100-year gap between the two outbreaks, the Great powers' propaganda shows its power in both pandemics by framing the dissenters.

\subsection{History behind the name "Spanish Flu."}

Until today, in many English-speaking countries, Great Influenza is titled with Spanish, which misled many ordinary people to believe that Spain was the origin of Great Influenza. However, Spain was not the birthplace of the virus.

The ugly nickname was the result of international relations and propaganda's work [12]. To a large extent, Spain was blamed for political reasons entirely, which can be divided into two parts: the unique position compared with the Allies [13], and its newspapers.

First, Spain was dissatisfied with the UK and France long before the 1910s because they unfairly distributed the colonies' interests with Spain. Moreover, countries that shared the same border with him had no friendly relation with him. Then, during WWI, Spain declared neutrality to respond to the demands of the Great powers. While de facto, it has a pro-German attitude which was shown perfectly during the Fernando Po Affair when the Allies even threatened to invade Spanish colonies to make Spain drive the German army away. Later, when its neighbors were in the same camp and all fighting against Germany. Spain kept its neutrality status. No doubt, its economy was saved by neutrality. However, entire Europe was hostile to Spain.

Second, Spanish newspapers reported the infection first because it had a neutral status, meaning it had little control over the press. Without military control over information flow, the press has the freedom to publish the truth. The Spanish newspapers gave the Flu full coverage, while many authorities decided to hide it for morale. When the symptoms of the epidemic were evident in the population, governments had to acknowledge the existence of the epidemic. Out of hostility, Europe named it the Spanish Flu.

Because the Great powers' propaganda was way too powerful, the whole world mistakenly believed that Spain was the sinner of Great Influenza. While since the development of modern medicine. In the 21 st century, many virologists are trying to determine the source of the virus by taking archaeological excavations in perpetually frozen soil. As a result, more and more evidence suggests that the virus was born in the USA in 1916. To tell, the propaganda of Great powers has a significant impact during the Great Influenza and on a country's reputation. 


\section{2 "Wuhan virus" and diplomatic battle.}

In the past few decades, the WHO has tried to avoid using country or nation to name the pandemic, in fear of starting hatred and race riots. Unfortunately, all its efforts vanished during the Covid-19 pandemic. The WHO has not confirmed where the virus' birthplace. However, the American government named it the 'Chinese virus' and the "Wuhan virus' at the first moment of the outbreak. Race riots happen all over the world. There was hate speech flowing online, and extremists targeted foreign companies and immigrant groups. The extreme thoughts in the USA had found a perfect excuse to perform social stigma. Asian face became the target, no matter the age or gender. Even 70-years old lady got attacked on the street in NYC in the daytime.

Indeed the social unrest always appears with the pandemic [14]. While this time, every individual was involved. Then the nickname argument transformed into a vaccine battle. The pandemic still enlarged social unrest and racial discrimination. Social campaigns such as 'Black Lives Matter', were followed by many others and became the hottest tag in west social media.

Covid-19 with the social media's "help" combined with the unsuccessful leadership of certain governments caused a wider, nastier, and childish diplomatic battle [15]. Some articles called it the death of classic diplomacy. When mass infection happened in the western world, America started to criticize China's illegal wildlife trade for being directly responsible for the outbreak and argues that China shall pay for it. China responded with a government decree to immediately close all animal trade. Moreover, meanwhile, China suspected that virus was from an American's lab. The virus raised a feud between the USA and China, which was the trade war's enlargement. This battle peaked when the former American president called out the Wuhan virus in front of the press in the white house. That made the global opinion full of extreme voice. Also made China had a stronger diplomatic attitude than ever.

Discrimination and diplomatic battle left propaganda and espionage with an excellent opportunity to manipulate the public will. All governments tried to justify their innocent, during which they used propaganda to reveal others' hidden histories. Many western countries' hidden history of ill-treating the indigenous has been exposed. For example, the history of genocide on the American continent has been deeply exposed, while gender unfairness in China has been exposed on a large scale. The process of defending governments' reputation has left problems to the post-epidemic international relations.

The reason for all the above was simple. First, it is to shift the focus and move the sight from the governments' mistaken actions, such as the denials about the existence of virus and explored public in danger. It is pretty standard when the medical resources run out and the public notices that the governments are responsible for the worse situation. Second, the Covid-19 gave the USA and China perfect timing to upgrade the conflicts, when they use propaganda to justify their regime' legitimacy.

The nickname caused the diplomatic battle between China and the USA during the pandemic and pushed the bilateral relationship to the lowest point. Also, it has exacerbated ideological rifts between the Great powers.

\section{IMPACT OF THE PANDEMICS :}

\subsection{Great Influenza}

It had far-reaching implications for the after-war world. In the European continent, all protests caused by the Great Influenza made better soil for the growth of racism and fascism. In the USA, the Spanish Flu allowed society have another excuse to blame everything on the poor and black [16]. The race riots were widespread in the USA, like race riots in Philadelphia, the Chicago race riots in 1919. The social unrest and Great Influenza continuously enlarged the hatred. There have been reports that connected Nazie's fast growth with the pandemic. Overall, for those areas already had extremists, the pandemic will exacerbate ethnic sentiment in the region.

Great Influenza indirectly amplifies the impact of WWI. Millions of human deaths made the market not have the same quantity of labor force. Furthermore, Influenza planted the seed of increased protectionism. The new technology invented before the war started to be used in production to fill the labor force's needs. The midwar economy was boosted, but soon, protectionism and tensive relations stopped it. Trade relations between European countries were irreconcilable because of protectionism. Peace smashed, when the US stock market crashed in 1929. Europe could not loan more money to up its economy. Furthermore, the Great powers tried appeasement to comfort the Nazi. When all the factors add up, the coming of WWII finally shattered people's illusion of peace.

As for the colonies, numerous colonists died because empires failed to fight the Great Influenza in colonies. The enormous death rate in India reached $5 \%$ of the total population, about 18 million. Many papers connected the number to later India' Independence and suggested that the pandemic indirectly made the colonized countries understand their position.

\subsection{COVID-19: what has it resulted in?}

Covid-19 is leaving a substantial impact on diplomacy and foreign affair. Due to social media, the diplomatic battle was seen by every people who have the internet. The image of all countries has been hurt. D. 
Tramp destroyed the US president's image. Chinese was portrayed as primitive people who drink blood and eat wild animals. Other than reputation, the partnership between allies and the leadership of the EU and USA were weakened. It is illustrated in the words of Pierre Lellouche: "mais la planète, en ce moment, me fait davantage penser au Radeau de la méduse de Géricault" [17]. When the USA refused to part with a pack of masks with Canada, when every mask that passed through a third country in Europe faced the risk of expropriation, all suggested that pandemic pushed international relations closer to realism. America and Europe's actions had a substantial impact on their leadership and reputation after the pandemic.

Because it happened with the trade war, different ideologic campuses have used the vaccine as a tool to manipulate international relations. They both tried to gain more partners or followers. Great powers only share their vaccine and pills with the most valuable and potential allies to prove their strength. As for those less valuable partners, the situation was much worse. As for allies like the Taiwan area, who have only geopolitical significance to America, vaccines with a lethality rate higher than average are all they can get. So does the isolation and quarantine policy was used for political reasons.

The Covid-19 generated the vacuum in the traditional conflict zone. That made its situation change fast. For example, in Afghanistan, a vacuum showed up when Americans pulled back their power from the famous empire's cemetery to rebalance the power into the Indian ocean, so the "former terrorist" took the opportunity and went back into power. Covid-19 left time and a chance for terrorists like the Taliban to decontrol their cage.

Strange economic phenomena begin to happen. The unemployment rate and labor gap are rising simultaneously in the USA. In China, in the short term, the deflation and power shortage draw the economy to keep dropping, and massive debt from the real-estate company is testing the bottom line of the party. Today the supply chain is not running smoothly. Exporters hardly find an empty container. However, trade protectionism [18] is fast rising. Energy security under the pandemic put more pressure on today's global safety situation.

\section{CONCLUSION}

These two nature disasters shared incredible similarities on the level of international relations. Not limited to their background, the process, and their effects. They both happen when the world rebalances power, and new power is challenging the former giant. Moreover, the tense relationship between countries made all governments hurt the truth to fulfill kinds of purpose at the beginning in both pandemics. During the pandemic, the propaganda of the Great powers all hard-worked aim to take down others' reputations and retain their influence.
Again, the world had not prepared to deal with the pandemic, and their reaction made the public confidence in the governments drop to the lowest point. Both pandemics generated social unrest targeted specific groups of people. Moreover, indirectly contributed to the growth of nationalism and extremism.

The Great Influenza illustrated that the global tension had not to be reduced due to the virus. Instead, it stimulates extreme power and the right-wing sentiments. Many experts blamed WWII on the Thucydides' trap when newborns challenged the international structure. However, the Great Influenza contributed a lot to the war. It exaggerates existing fissures in international relations and pushes nationalist and extremist forces into the hopeless crowd. More important is that we should learn from the previous one, subduing the extremist party worldwide, vigilantly and actively facing the emerging dangers and making positive responses to ensure a peaceful international environment.

Now, tons of voices warning that the USA policymaker should early mobilize the resource to restrain the future action of China have spread on the internet. Public opinion in more countries is controlled and becomes more radical and unfriendly. People a hundred years ago dreamed of a perfect world after the epidemic. However, the economic crisis and WWII followed. We should believe that pandemic will not awaken the awareness of humanity and kind intentions, reversing today's international situation.

\section{REFERENCES}

[1] NIALL P. A. S. JOHNSON and JUERGEN MUELLER, Updating the Accounts: Global Mortality of the 1918-1920 "Spanish" Influenza Pandemic page, 108

[2] Ian Mills "India experience" n.4

[3] History of 1918 Flu Pandemic, Centers for Disease Control and Prevention, https://www.cdc.gov/flu/pandemic-resources/1918commemoration/1918-pandemic-history.htm

[4] NIALL P. A. S. JOHNSON and JUERGEN MUELLER, Updating the Accounts: Global Mortality of the 1918-1920 "Spanish" Influenza Pandemic page 112

[5] Brazil political risk 2021, BCW Brazil, https://bcwglobal.com/br/latest/news/2021-06-18-brazilpolitical-risks-2021

[6] Jean-Pierre Robin, Face au coronavirus, la vérité des chiffres s'avance masquée, 15/03/2020, Le Figaro. https://www.lefigaro.fr/conjoncture/face-aucoronavirus-la-verite-des-chiffres-s-avancemasquee-20200315 
[7] The Threat of Pandemic Influenza : Are we ready, workshop summary, NCBI, https:/www.ncbi.nlm.nih.gov/books/NBK22148/

[8] Catharine Arnold, Pandemic 1918: Eyewitness Accounts from the Greatest Medical Holocaust in Modern History.

[9] National Influenza Surveillance Programme, 2017 edition, National Health Commission of the PRC,3,30,2017, http://www.nhc.gov.cn/cmssearch/xxgk/getManuscriptXxgk.htm?id=ed1498d9 e64144738cc7f8db61a39506

[10] Isabelle Lasserre, Pierre Lellouche: «La pandémie accélérera la montée en puissance de la Chine», 30/03/2020, Le Figaro. https://www.lefigaro.fr/international/pierrelellouche-la-pandemie-accelerera-la-montee-enpuissance-de-la-chine-20200330

[11] Henry Kissinger, The pandemic Coronavirus always changes the world order. The Wall Street Journal (США), пандемия коронавируса навсегда изменит мировой порядок, https://inosmi.ru/politic/20200408/247221772.html.

[12] Святослав Князев, «Испанский» ужас: что известно о самой страшной пандемии в истории человечества, Svatoslav Knyazev, < Spanish Flu> horror: what is known about the worst pandemic in the history of mankind. 11,03,2018. https://russian.rt.com/science/article/490710ispanskii-gripp-epidemiya

[13] Mednikov I.Yu. Historical Significance of the Spanish Neutrality in the First World War. MGIMO Review of International Relations. 2014;(4(37)):2634. (In Russ.) https://doi.org/10.24833/2071-81602014-4-37-26-34

[14] Laura Andrieu, Pourquoi des conflits sociaux apparaissent-ils en temps de pandémie?, 30/01/2021. Le Figaro. https://www.lefigaro.fr/international/pourquoi-desconflits-sociaux-apparaissent-ils-en-temps-depandemie-20210130

[15] Bert Hofman, The Global Pandemic, Horizons: Journal of International Relations and Sustainable Development , No. 16, Pandemics \& Geopolitics: The Quickening (SPRING 2020), pp. 60-69 (10 pages)

https://www.jstor.org/stable/48573749?readnow $=1 \&$ refreqid $=$ excelsior $\% 3$ A070bf4098a021 cd7 cd8ca1fc25dddce5\&seq=10\#page_scan_tab_conte nts

[16] Kristen Rogers, White violence and Black protests during the 1918 flu have a lesson for today. CNN. https://edition.cnn.com/2021/02/16/health/1918-

flu-lessons-philadelphia-race-riots-

wellness/index.html

[17] translation as "but this planet at this moment, remaindered me of Géricault's Raft of the Medusa. It is the region of everyone for himself or herself."

[18] Bert Hofman, The Global Pandemic: How COVID19 has Changed the World, CIRSD. https://www.cirsd.org 